\title{
ASSESSMENT OF RADIOLOGICAL CHANGES IN THE HANDS AND FEET IN RHEUMATOID ARTHRITIS THEIR CORRELATION WITH PROGNOSIS*
}

\author{
A. K. THOULD AND G. SIMON \\ St. Bartholomew's Hospital, London
}

It is well known that a normal hand radiograph is occasionally encountered in patients with rheumatoid arthritis in whom radiographs of the feet show the classical changes of the disease. Being unaware of any description in the literature of the incidence of this state of affairs, we were prompted to undertake a survey of radiographs of the hands and feet in rheumatoid arthritis, with the primary aim of discovering just how common was this finding of a negative hand radiograph in association with a positive foot radiograph. Our secondary aim was to correlate radiological changes in the hands and feet with prognosis.

\section{Material and Criteria for Radiographic Diagnosis}

All those patients suffering from rheumatoid arthritis with at least one complete set of hand and foot radiographs taken on the same date were reviewed. Inevitably those patients seen in this hospital with rheumatoid arthritis are highly selected, and our findings can lay no claim to be typical of the disease at large, but only of our particular practice. Only those who satisfied the criteria of the American Rheumatism Association (Ropes, Bennett, Cobb, Jacox, and Jessar, 1959) for classical or definite rheumatoid arthritis were accepted, and 109 patients conformed to these requirements. The notes were inadequate in two and the radiographs could not be found in two more, leaving 105 to form the subject of this review.

The radiographs were examined by both of us, and one of us was kept unaware of the clinical state of each patient. A proportion of the radiographs was reexamined at random without the foreknowledge of this examiner, and good agreement in the dual reports on these films was obtained. Almost every patient had had serial examinations for haemoglobin levels, latex-fixation test titres, and erythrocyte sedimentation rates (E.S.R.). When correlating radiological changes and clinical findings, the lowest haemoglobin level and highest E.S.R. obtained in each patient were used. The latex-fixation

*Presented at a meeting of the Heberden Society on February 26,
1965 . test was regarded as positive if it had been so recorded at some stage of the disease.

The radiological changes in the hands and feet were $N$ critically assessed by the criteria of the "Atlas of Standard 0 Radiographs of Arthritis" (C.I.O.M.S., 1963), and graded 0 to 3. Our Grade 0 was equivalent to Grades 0 and 1 of Kellgren and Lawrence (1957), our Grade 2 to their Grade 3, and our Grade 3 to their Grade 4. This change was made as it was felt that the grading of doubt- $\overrightarrow{0}$ ful and non-specific changes as a separate category would 8 not be helpful for our purposes. Only where definite and undoubted changes of rheumatoid arthritis were present would we place a radiograph in our Grade 1 .

Of the 105 patients reviewed, 44 were male and 61 female, a sex ratio of 139 females for every 100 males. ฉँ The average age of the group as a whole was $52 \cdot 1$ years $\mathbb{Q}$ (range 17 to 80 ), the females being slightly younger $(50 \cdot 5 \stackrel{2}{\Rightarrow}$ years) than the males ( $54 \cdot 4$ years). As the results in both 윽 sexes showed no significant differences, they were combined for the purposes of analysis. We have not undertaken formal tests of significance when analysing our results in order not to give undue weight to figures which, because of the small numbers involved, can only indicate trends.

There is a clear excess of persons aged 31 to 70 years in our series as compared with the general population 0 (General Register Office, 1964), and a deficiency of those aged less than 30 years. Most patients first develop their 윽 rheumatoid arthritis at the age of 25 to 55 years (LewisFaning, 1950), and as the mortality rate is so low in this disease the expected prevalence rate continues to rise at least up to the age of 60 years (Miall, 1955).

We found a sex ratio of males to females of 1 to $1 \cdot 38$. This is a somewhat higher proportion of males than is $\mathrm{N}$ usually found; ratios of 1 to 3 are often quoted (Copeman, $\omega$ 1955), though Lewis-Faning reported a ratio of 1 to $1 \cdot 62$.

The mean age of our patients was higher than that 0 found by Lewis-Faning, but it is known that the male $\overparen{\Phi}$ incidence more closely approaches the female in older age $\stackrel{\mathscr{C}}{?}$ groups (Cecil and Kammerer, 1951) and this probably 0 accounts for the discrepancy. All of our patients reached Grades 2 or 3 of the American Rheumatism $\overrightarrow{\mathbb{D}}$

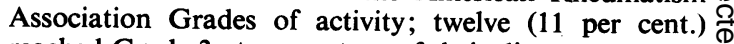
reached Grade 3 at some stage of their disease. 


\section{Results}

Radiological Evidence of Bone Changes.-Our survey showed that in no less than seventeen patients (16 per cent.) the foot radiographs were positive when those of the hand were negative (Fig. 1), and positive radiographic appearances of rheumatoid arthritis were found in both hands and feet in 79 (75 per cent.) (see Table I), so that 96 patients (91 per cent.) showed positive radiological changes of the disease present. In no case was the hand radiograph positive and that of the foot negative. In seven of the seventeen with positive foot but negative hand radiographs later films were available; in five the hands were still negative at periods up to 2 years later, but the remaining two showed positive radiographic findings in the hands by the third year. In two of those whose hands still remained negative after 2 years the feet had deteriorated, with an increase of one and $\frac{0}{\infty}$ five metatarsal heads involved respectively. The two whose hands became positive after 3 years $\stackrel{0}{\rightarrow}$ showed no further deterioration in the feet.

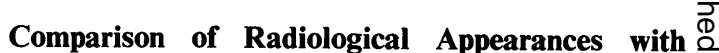
Clinical Findings. - There is a striking correlation between duration of disease and the occurrence of $\vec{\circ}$ the classical radiological appearances of rheumatoid disease in the hand and foot. Where either the $\vec{\omega}$ hand or both hand and foot radiographs are nega- $\frac{\sigma}{S}$ tive, the majority of patients have had the disease for $\frac{0}{2}$ less than 5 years. However, where both hand and is foot show positive radiological changes, well over $\omega$ half have had the disease for more than 5 years.
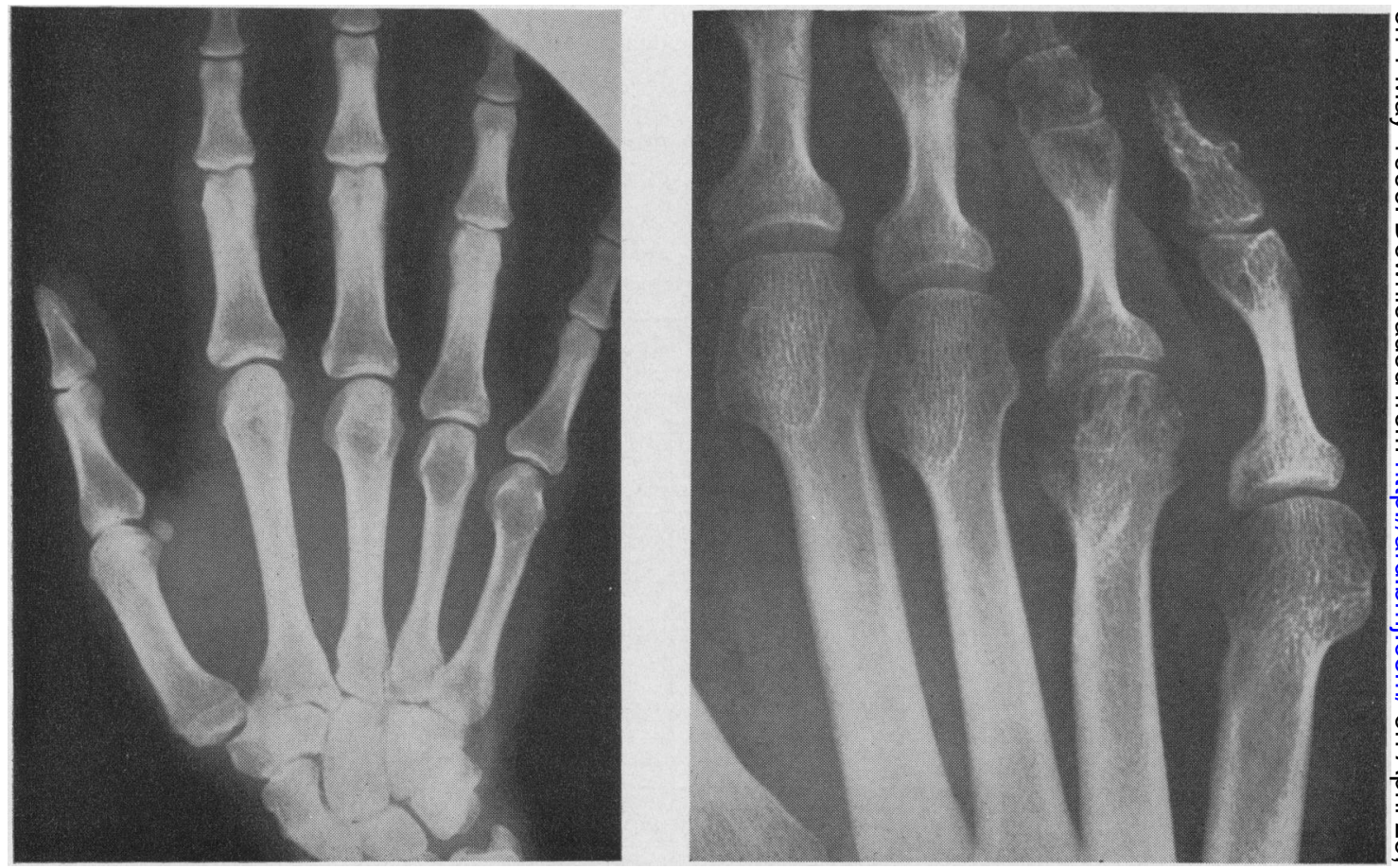

Fig. 1.-Radiograph showing a normal hand but rheumatoid erosions in the foot, in a female aged 58 years, who had had symptoms for 2 years.

TABLE I

DISTRIBUTION OF RADIOLOGICAL CHANGES

\begin{tabular}{|c|c|c|c|c|c|c|c|}
\hline \multicolumn{2}{|c|}{$\begin{array}{l}\text { Hands Positive } \\
\text { Feet Positive }\end{array}$} & \multicolumn{2}{|c|}{$\begin{array}{l}\text { Hands Negative } \\
\text { Feet Positive }\end{array}$} & \multicolumn{2}{|c|}{$\begin{array}{c}\text { Hands Negative } \\
\text { Feet Negative }\end{array}$} & \multicolumn{2}{|c|}{ Total } \\
\hline No. & Percentage & No. & Percentage & No. & Percentage & No. & Percentage \\
\hline 79 & 75 & 17 & 16 & 9 & 9 & 105 & 100 \\
\hline
\end{tabular}


There is some evidence (Table II) of an excess of persons aged 41 years or more in the group with both hand and foot radiographs positive, or in those with foot positive but hand negative, if assessed by age at interview. The numbers are small, however, and too much significance should not be read into them. When these patients are assessed by age at onset of the disease these differences are much less obvious. There is a probable correlation between extent of radiological change and the degree of elevation of the E.S.R., and this is also true of the latex-fixation test (Fig. 2). Where both hand and foot films are positive, the greater proportion of patients are latex positive and more likely to have a raised E.S.R. Where both hand and foot films are negative, the reverse is true. Where only the foot films are positive the findings are intermediate. There is a tendency for the haemoglobin to be less than 65 per cent. Haldane in those with both positive hand and foot films. The extent of disease, as judged by the number of groups of joints involved, seems to be similar in the three groups. Those with positive hand and foot radiographs are more likely to have nodules present (33 per cent.) than those with

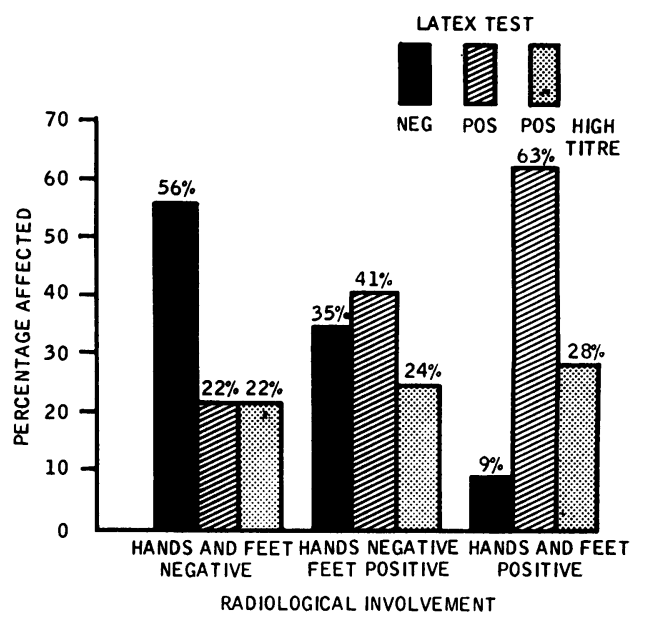

Fig. 2.-Radiological appearances correlated with latex-fixation test. negative films in the hands only (18 per cent.), or in 윽 both hands and feet ( 22 per cent.). Table II shows that those with positive hand and foot films are much more likely to have been treated with gold or corticosteroids than those with one or both films negative. $\overrightarrow{\mathscr{\theta}}$

TABLE II

COMPARISON OF DISTRIBUTION OF RADIOLOGICAL DISEASE WITH CLINICAL PARAMETERS

\begin{tabular}{|c|c|c|c|c|c|c|c|c|c|}
\hline \multicolumn{2}{|c|}{ Clinical Parameters } & \multicolumn{2}{|c|}{$\begin{array}{l}\text { Hands Negative } \\
\text { Feet Negative }\end{array}$} & \multicolumn{2}{|c|}{$\begin{array}{l}\text { Hands Negative } \\
\text { Feet Positive }\end{array}$} & \multicolumn{2}{|c|}{$\begin{array}{l}\text { Hands Positive } \\
\text { Feet Positive }\end{array}$} & \multicolumn{2}{|c|}{ Total } \\
\hline & & No. & Percentage & No. & Percentage & No. & Percentage & No. & Percentage \\
\hline $\begin{array}{l}\text { Latex- } \\
\text { fixation } \\
\text { Test }\end{array}$ & $\begin{array}{r}- \text { ve } \\
+v e \\
\text { High titre }\end{array}$ & $\begin{array}{l}5 \\
2 \\
2\end{array}$ & $\begin{array}{l}56 \\
22 \\
22\end{array}$ & $\begin{array}{l}6 \\
7 \\
4\end{array}$ & $\begin{array}{l}35 \\
41 \\
24\end{array}$ & $\begin{array}{r}7 \\
50 \\
22\end{array}$ & $\begin{array}{r}9 \\
63 \\
28\end{array}$ & $\begin{array}{l}18 \\
59 \\
28\end{array}$ & $\begin{array}{l}17 \\
56 \\
27\end{array}$ \\
\hline $\begin{array}{l}\text { Hb } \\
\text { (percentage } \\
\text { Haldane) }\end{array}$ & $\begin{array}{r}-65 \\
-85 \\
>85 \\
\text { Not known }\end{array}$ & $\begin{array}{l}0 \\
6 \\
3 \\
0\end{array}$ & $\begin{array}{r}0 \\
67 \\
33 \\
0\end{array}$ & $\begin{array}{l}2 \\
9 \\
6 \\
0\end{array}$ & $\begin{array}{r}12 \\
53 \\
35 \\
0\end{array}$ & $\begin{array}{r}15 \\
41 \\
22 \\
1\end{array}$ & $\begin{array}{r}19 \\
52 \\
28 \\
1\end{array}$ & $\begin{array}{r}17 \\
56 \\
31 \\
1\end{array}$ & $\begin{array}{r}16 \\
53 \\
30 \\
1\end{array}$ \\
\hline $\begin{array}{l}\text { E.S.R. } \\
\text { (mm./1st hr } \\
\text { Westergren) }\end{array}$ & $\begin{array}{r}-20 \\
-60 \\
>60 \\
\text { Not known }\end{array}$ & $\begin{array}{l}6 \\
3 \\
0 \\
0\end{array}$ & $\begin{array}{r}67 \\
33 \\
0 \\
0\end{array}$ & $\begin{array}{l}6 \\
9 \\
1 \\
1\end{array}$ & $\begin{array}{r}35 \\
53 \\
6 \\
6\end{array}$ & $\begin{array}{r}13 \\
42 \\
23 \\
1\end{array}$ & $\begin{array}{r}16 \\
54 \\
29 \\
1\end{array}$ & $\begin{array}{r}25 \\
54 \\
24 \\
2\end{array}$ & $\begin{array}{r}24 \\
51 \\
23 \\
2\end{array}$ \\
\hline $\begin{array}{l}\text { No. of Groups } \\
\text { of Joints } \\
\text { Involved }\end{array}$ & $\begin{array}{l}-2 \\
-6 \\
-8\end{array}$ & $\begin{array}{l}0 \\
7 \\
2\end{array}$ & $\begin{array}{r}0 \\
78 \\
22\end{array}$ & $\begin{array}{r}0 \\
15 \\
2\end{array}$ & $\begin{array}{r}0 \\
88 \\
12\end{array}$ & $\begin{array}{r}3 \\
59 \\
17\end{array}$ & $\begin{array}{r}44 \\
74 \\
22\end{array}$ & $\begin{array}{r}3 \\
81 \\
21\end{array}$ & $\begin{array}{r}3 \\
77 \\
20\end{array}$ \\
\hline $\begin{array}{l}\text { Duration of } \\
\text { Disease (yrs) }\end{array}$ & $\begin{array}{l}-5 \\
>5\end{array}$ & $\begin{array}{l}8 \\
1\end{array}$ & $\begin{array}{l}89 \\
11\end{array}$ & $\begin{array}{r}15 \\
2\end{array}$ & $\begin{array}{l}88 \\
12 \\
\end{array}$ & $\begin{array}{l}35 \\
44\end{array}$ & $\begin{array}{l}44 \\
56\end{array}$ & $\begin{array}{l}58 \\
47\end{array}$ & $\begin{array}{l}55 \\
45\end{array}$ \\
\hline Nodules & $\begin{array}{l}\text { Present } \\
\text { Absent }\end{array}$ & 2 & 22 & $\begin{array}{r}3 \\
14\end{array}$ & $\begin{array}{l}18 \\
82\end{array}$ & $\begin{array}{l}26 \\
53\end{array}$ & $\begin{array}{l}33 \\
67\end{array}$ & $\begin{array}{l}31 \\
74\end{array}$ & $\begin{array}{l}30 \\
70\end{array}$ \\
\hline $\begin{array}{l}\text { Age at } \\
\text { Interview } \\
\text { (yrs) }\end{array}$ & $\begin{array}{r}-40 \\
41-60 \\
>60 \\
\end{array}$ & $\begin{array}{l}4 \\
4 \\
1 \\
\end{array}$ & $\begin{array}{l}44 \cdot 5 \\
44 \cdot 5 \\
11 \\
\end{array}$ & $\begin{array}{r}4 \\
11 \\
2\end{array}$ & $\begin{array}{l}24 \\
64 \\
12 \\
\end{array}$ & $\begin{array}{l}11 \\
45 \\
23 \\
\end{array}$ & $\begin{array}{l}14 \\
57 \\
29\end{array}$ & $\begin{array}{l}19 \\
60 \\
26 \\
\end{array}$ & $\begin{array}{l}18 \\
57 \\
25 \\
\end{array}$ \\
\hline $\begin{array}{l}\text { Age at } \\
\text { Onset } \\
\text { (yrs) }\end{array}$ & $\begin{array}{r}-40 \\
41-60 \\
>60\end{array}$ & $\begin{array}{l}4 \\
4 \\
1\end{array}$ & $\begin{array}{l}44 \cdot 5 \\
44 \cdot 5 \\
11\end{array}$ & $\begin{array}{r}6 \\
10 \\
1\end{array}$ & $\begin{array}{r}35 \\
59 \\
6\end{array}$ & $\begin{array}{l}27 \\
42 \\
10\end{array}$ & $\begin{array}{l}34 \\
53 \\
13 \\
\end{array}$ & $\begin{array}{l}37 \\
56 \\
12\end{array}$ & $\begin{array}{l}36 \\
53 \\
11\end{array}$ \\
\hline \multirow{2}{*}{ Therapy } & $\begin{array}{cl}\text { Cortico- } & \text { Yes } \\
\text { steroid } & \text { No }\end{array}$ & $\begin{array}{l}1 \\
8\end{array}$ & $\begin{array}{l}11 \\
89\end{array}$ & $\begin{array}{r}3 \\
14\end{array}$ & $\begin{array}{l}18 \\
82\end{array}$ & $\begin{array}{l}37 \\
42\end{array}$ & $\begin{array}{l}46 \\
54\end{array}$ & $\begin{array}{l}41 \\
64\end{array}$ & $\begin{array}{l}39 \\
61\end{array}$ \\
\hline & $\begin{array}{l}\text { Yes } \\
\text { No }\end{array}$ & $\begin{array}{l}0 \\
9\end{array}$ & $\begin{array}{r}0 \\
100\end{array}$ & $\begin{array}{r}3 \\
14\end{array}$ & $\begin{array}{l}18 \\
82\end{array}$ & $\begin{array}{l}24 \\
55\end{array}$ & $\begin{array}{l}30 \\
70\end{array}$ & $\begin{array}{l}27 \\
78\end{array}$ & $\begin{array}{l}26 \\
74\end{array}$ \\
\hline
\end{tabular}


Metatarsal Head Involvement.-Fig. 3 shows that the 5th metatarsal head is that most commonly involved by rheumatoid erosions, and the first the least. There is a good correlation between the extent of metatarsal head involvement and the degree of severity of radiological changes in the hand. Where only Grade 1 changes were present in the hands, 91 per cent. of the patients had four or less metatarsal heads involved in both feet. Where the hand films showed Grade 2 or 3 changes, threequarters of the patients had more than five metatarsals involved, and one-third had more than eight affected. The average total number of metatarsals involved in both feet in patients with a negative latex-fixation test is $3 \cdot 5$. In those who are latex positive, the average total number involved is $4 \cdot 4$, and in those with a high titre for the latex test (equal to or greater than 1 in 2,560) the average number of metatarsal heads involved is $5 \cdot 3$. Four (4 per cent.) of the patients had involvement of the distal interphalangeal joints in the fingers, and in five ( 5 per cent.) whole-hand decalcification was present. This decalcification improved in one person over a 3-year period. Three ( 3 per cent.) had obvious periostitis of the finger bones or metatarsals.

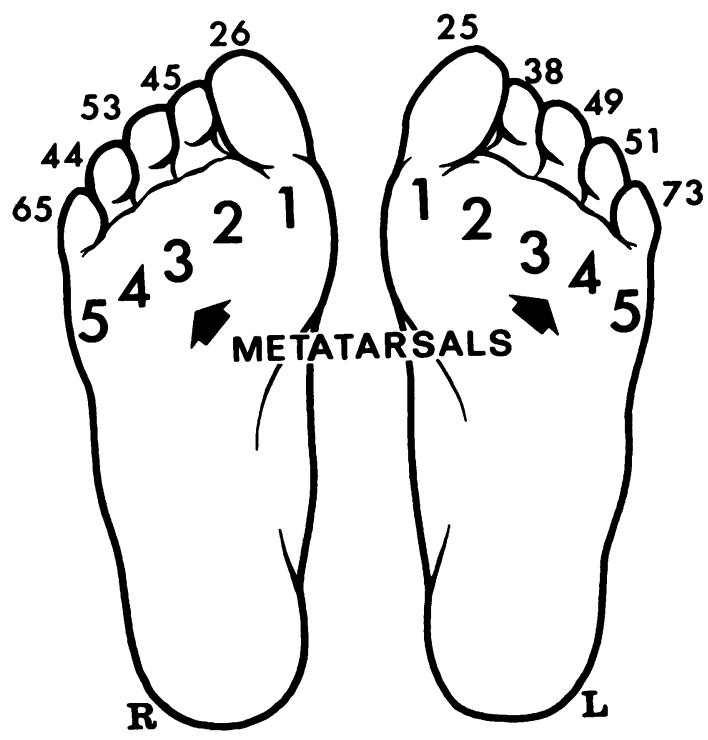

Fig. 3.-Diagram showing the number of times each metatarsal head was involved by rheumatoid erosions.
Persistently Painless Feet.-In sixteen (15 per cent.) patients the feet had never been painful, though all of them had positive radiological appearances of rheumatoid arthritis in the feet. If this group with persistently symptomless feet is compared with those whose feet have been painful at some time in the course of the disease, a few differences emerge. There is an excess of those whose disease has been present for less than 5 years in the painless group. However, the age distribution by decades $c$ reveals no clear excess of those with painless feet at $\overrightarrow{0}$ any particular age, whether assessed by age at interview or by age at onset. There is a tendency for $\bar{\omega}$ those with persistently painless feet to have a smaller number of metatarsal heads involved. If extent of $\bar{a}$ disease is studied, as shown by the number of groups $N$ of joints involved, then an excess is apparent of less $\omega$ extensive disease in those with painless feet.

Symmetry of Radiological Involvement.-The more severe the radiological involvement the less likely there was to be asymmetry. Where the degree of foot involvement was only Grade 1 , thirteen of $46 \stackrel{\leftrightarrow}{\circ}$ (28 per cent.) showed asymmetrical radiological $\%$ disease. Of these thirteen, nine showed more severe $\square$ changes on the right than the left. Where the changes in the feet were Grade 2 or 3, only two of fifty (4 per cent.) showed any asymmetry, and in both of them the changes were slightly worse on the left. $\stackrel{\mathbb{Q}}{\varnothing}$ Of fifteen who showed asymmetry, therefore, nine $\overrightarrow{\vec{D}}$ were worse on the right side and six on the left (Table $\frac{3}{3}$ III).

TABLE III

SYMMETRY OF RADIOLOGICAL APPEARANCES

\begin{tabular}{|c|c|c|c|c|}
\hline \multirow{2}{*}{$\begin{array}{l}\text { Grade of Foot } \\
\text { Involvement } \\
\text { on } X \text {-ray }\end{array}$} & \multirow{2}{*}{ Symmetrical } & \multicolumn{2}{|c|}{ Asymmetrical } & \multirow{2}{*}{ Total } \\
\hline & & Right & Left & \\
\hline $\begin{array}{l}1 \\
2 \\
3\end{array}$ & $\begin{array}{l}33 \\
33 \\
15\end{array}$ & $\begin{array}{l}9 \\
0 \\
0\end{array}$ & $\begin{array}{l}4 \\
1 \\
1\end{array}$ & $\begin{array}{l}46 \\
34 \\
16\end{array}$ \\
\hline Total & 81 & 9 & 6 & 96 \\
\hline
\end{tabular}

Comparison of Severity of Radiological Appear- $\omega$ ances with Clinical Findings.-If the severity of radiological appearances is compared with our clinical findings, similar correlations to those found in the first paragraph of this section are observed. Our results, tabulated by degree of radiological $\frac{}{\circ}$ involvement of hand and foot, are set out in full in $\stackrel{\mathbb{\sigma}}{\circ}$ Table IV (overleaf). 


\begin{tabular}{|c|c|c|c|c|c|c|c|c|c|c|}
\hline \multirow{4}{*}{\multicolumn{3}{|c|}{ Clinical Parameters }} & \multicolumn{8}{|c|}{ Grade of Radiological Involvement } \\
\hline & & & & & \multicolumn{4}{|c|}{ Hands } & & (2) \\
\hline & & & \multicolumn{2}{|c|}{0} & \multicolumn{2}{|c|}{1} & \multicolumn{2}{|c|}{2} & \multicolumn{2}{|c|}{3} \\
\hline & & & No. & Percentage & No. & Percentage & No. & Percentage & No. & $P_{\varepsilon}^{-}$ \\
\hline $\begin{array}{l}\text { Latex- } \\
\text { fixation } \\
\text { Test }\end{array}$ & Hig & $\begin{array}{r}-v e \\
+v e \\
h \text { titre } \\
\end{array}$ & $\begin{array}{r}11 \\
9 \\
6 \\
\end{array}$ & $\begin{array}{l}42 \\
35 \\
23 \\
\end{array}$ & $\begin{array}{r}2 \\
22 \\
6 \\
\end{array}$ & $\begin{array}{r}7 \\
73 \\
20 \\
\end{array}$ & $\begin{array}{r}3 \\
18 \\
11 \\
\end{array}$ & $\begin{array}{r}9 \\
57 \\
34 \\
\end{array}$ & $\begin{array}{r}2 \\
10 \\
5 \\
\end{array}$ & $\begin{array}{l}\mathbb{1} 12 \\
\stackrel{1}{2} 59 \\
\stackrel{2}{2} 29\end{array}$ \\
\hline $\begin{array}{l}\text { Hb } \\
\text { (Percentage } \\
\text { Haldane) }\end{array}$ & Not & $\begin{array}{r}-65 \\
-85 \\
>85 \\
\text { known } \\
\end{array}$ & $\begin{array}{r}2 \\
15 \\
9 \\
0 \\
\end{array}$ & $\begin{array}{r}8 \\
57 \\
35 \\
0 \\
\end{array}$ & $\begin{array}{r}5 \\
13 \\
11 \\
1 \\
\end{array}$ & $\begin{array}{r}17 \\
43 \\
37 \\
3\end{array}$ & $\begin{array}{r}7 \\
17 \\
8 \\
0\end{array}$ & $\begin{array}{r}22 \\
53 \\
25 \\
0\end{array}$ & $\begin{array}{r}3 \\
11 \\
3 \\
0\end{array}$ & $\begin{array}{r}\overrightarrow{18} \\
064 \\
\overrightarrow{\overrightarrow{1}} 18 \\
\overrightarrow{0} \quad 0\end{array}$ \\
\hline \multicolumn{2}{|c|}{$\begin{array}{l}\text { E.S.R. } \\
\text { (mm./1st hr } \\
\text { Westergren) }\end{array}$} & $\begin{array}{r}-20 \\
-60 \\
>60 \\
\text { known } \\
\end{array}$ & $\begin{array}{r}12 \\
12 \\
1 \\
1 \\
\end{array}$ & $\begin{array}{r}46 \\
46 \\
4 \\
4 \\
\end{array}$ & $\begin{array}{r}5 \\
17 \\
7 \\
1 \\
\end{array}$ & $\begin{array}{r}17 \\
57 \\
23 \\
3\end{array}$ & $\begin{array}{r}5 \\
18 \\
9 \\
0 \\
\end{array}$ & $\begin{array}{r}16 \\
57 \\
27 \\
0 \\
\end{array}$ & $\begin{array}{l}3 \\
7 \\
7 \\
0 \\
\end{array}$ & 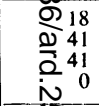 \\
\hline \multicolumn{2}{|c|}{$\begin{array}{l}\text { No. of Groups } \\
\text { of Joints } \\
\text { Involved }\end{array}$} & $\begin{array}{l}-2 \\
-6 \\
-8 \\
\end{array}$ & $\begin{array}{r}0 \\
22 \\
4 \\
\end{array}$ & $\begin{array}{r}0 \\
85 \\
15 \\
\end{array}$ & $\begin{array}{r}3 \\
21 \\
6\end{array}$ & $\begin{array}{l}10 \\
70 \\
20\end{array}$ & $\begin{array}{r}0 \\
25 \\
7 \\
\end{array}$ & $\begin{array}{r}0 \\
78 \\
22 \\
\end{array}$ & $\begin{array}{r}0 \\
13 \\
4\end{array}$ & $\begin{array}{l}0 \\
\omega_{76} \\
N^{24}\end{array}$ \\
\hline \multicolumn{2}{|c|}{$\begin{array}{l}\text { Duration of } \\
\text { Disease (yrs) }\end{array}$} & $\begin{array}{l}-5 \\
>5 \\
\end{array}$ & $\begin{array}{r}23 \\
3 \\
\end{array}$ & $\begin{array}{l}88 \\
12 \\
\end{array}$ & $\begin{array}{l}20 \\
10 \\
\end{array}$ & $\begin{array}{l}66 \\
34 \\
\end{array}$ & $\begin{array}{l}12 \\
20\end{array}$ & $\begin{array}{l}39 \\
61 \\
\end{array}$ & $\begin{array}{r}3 \\
14 \\
\end{array}$ & \\
\hline \multicolumn{2}{|l|}{ Nodules } & $\begin{array}{l}\text { Present } \\
\text { Absent }\end{array}$ & $21^{5}$ & $\begin{array}{l}19 \\
81 \\
\end{array}$ & $\begin{array}{r}7 \\
23 \\
\end{array}$ & $\begin{array}{l}23 \\
77 \\
\end{array}$ & $\begin{array}{l}12 \\
20\end{array}$ & $\begin{array}{l}38 \\
62 \\
\end{array}$ & $\begin{array}{r}7 \\
10\end{array}$ & \\
\hline \multicolumn{2}{|l|}{$\begin{array}{l}\text { Age at } \\
\text { Interview } \\
\text { (yrs) }\end{array}$} & $\begin{array}{r}-40 \\
41-60 \\
>60 \\
\end{array}$ & $\begin{array}{r}8 \\
15 \\
3\end{array}$ & $\begin{array}{l}30 \cdot 5 \\
58 \\
11 \cdot 5 \\
\end{array}$ & $\begin{array}{r}8 \\
18 \\
4 \\
\end{array}$ & $\begin{array}{l}26 \\
61 \\
13 \\
\end{array}$ & $\begin{array}{l}3 \\
19 \\
10 \\
\end{array}$ & $\begin{array}{r}9 \\
60 \\
31 \\
\end{array}$ & $\begin{array}{l}0 \\
8 \\
9\end{array}$ & $\begin{array}{l}\stackrel{\infty}{<} \quad 0 \\
\overrightarrow{0} 57 \\
0\end{array}$ \\
\hline \multicolumn{2}{|l|}{$\begin{array}{l}\text { Age at } \\
\text { Onset } \\
\text { (yrs) }\end{array}$} & $\begin{array}{r}-40 \\
41-60 \\
>60\end{array}$ & $\begin{array}{r}10 \\
14 \\
2\end{array}$ & $\begin{array}{r}38 \\
55 \\
7\end{array}$ & $\begin{array}{r}11 \\
17 \\
2\end{array}$ & $\begin{array}{r}37 \\
56 \\
7 \\
\end{array}$ & $\begin{array}{r}12 \\
16 \\
4\end{array}$ & $\begin{array}{l}37 \\
50 \\
13 \\
\end{array}$ & $\begin{array}{l}4 \\
9 \\
4\end{array}$ & \\
\hline \multirow{2}{*}{ Therapy } & $\begin{array}{r}\text { Cortico- } \\
\text { steroids }\end{array}$ & $\begin{array}{l}\text { Yes } \\
\text { No } \\
\end{array}$ & 23 & $\begin{array}{l}11 \cdot 5 \\
88 \cdot 5 \\
\end{array}$ & $\begin{array}{l}16 \\
14 \\
\end{array}$ & $\begin{array}{l}53 \\
47 \\
\end{array}$ & $\begin{array}{l}14 \\
18 \\
\end{array}$ & $\begin{array}{l}43 \\
57 \\
\end{array}$ & $\begin{array}{l}8 \\
9\end{array}$ & $\begin{array}{l}\geqq 47 \\
\vdots \\
\end{array} 53$ \\
\hline & Gold & $\begin{array}{l}\text { Yes } \\
\text { No }\end{array}$ & $\begin{array}{r}4 \\
22\end{array}$ & $\begin{array}{l}15 \\
85\end{array}$ & $\begin{array}{r}4 \\
26\end{array}$ & $\begin{array}{l}13 \\
87\end{array}$ & $\begin{array}{l}12 \\
20\end{array}$ & $\begin{array}{l}38 \\
62\end{array}$ & $\begin{array}{r}7 \\
10\end{array}$ & 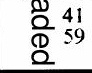 \\
\hline
\end{tabular}

There is a probable correlation between age at interview and degree of hand and foot involvement, as judged by radiological appearances (Fig. 4). No such correlation exists with age at onset. Practically all patients with Grade 3 changes in the hands and feet are above 41 years of age.
The proportion aged 40 years or less becomes increasingly smaller with advance in severity of radiological changes. The presence of subcutaneous and flexor tendon nodules bears a marked relationship with increasing severity of changes in the hand films. Nearly half of those with Grade 3 severity 3
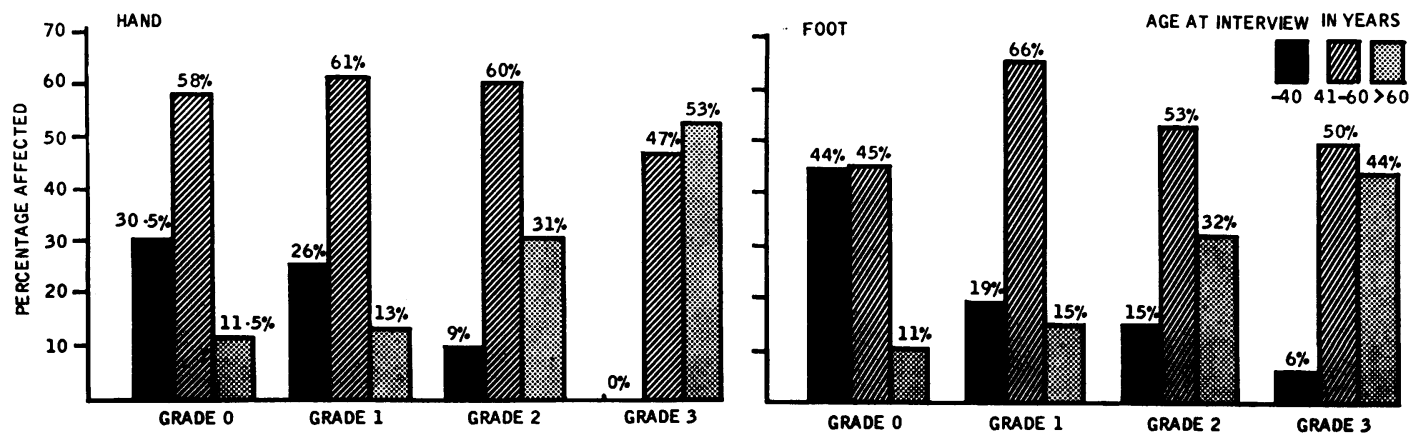

Fig. 4.-Degree of radiological involvement in hand and foot correlated with age at interview. 


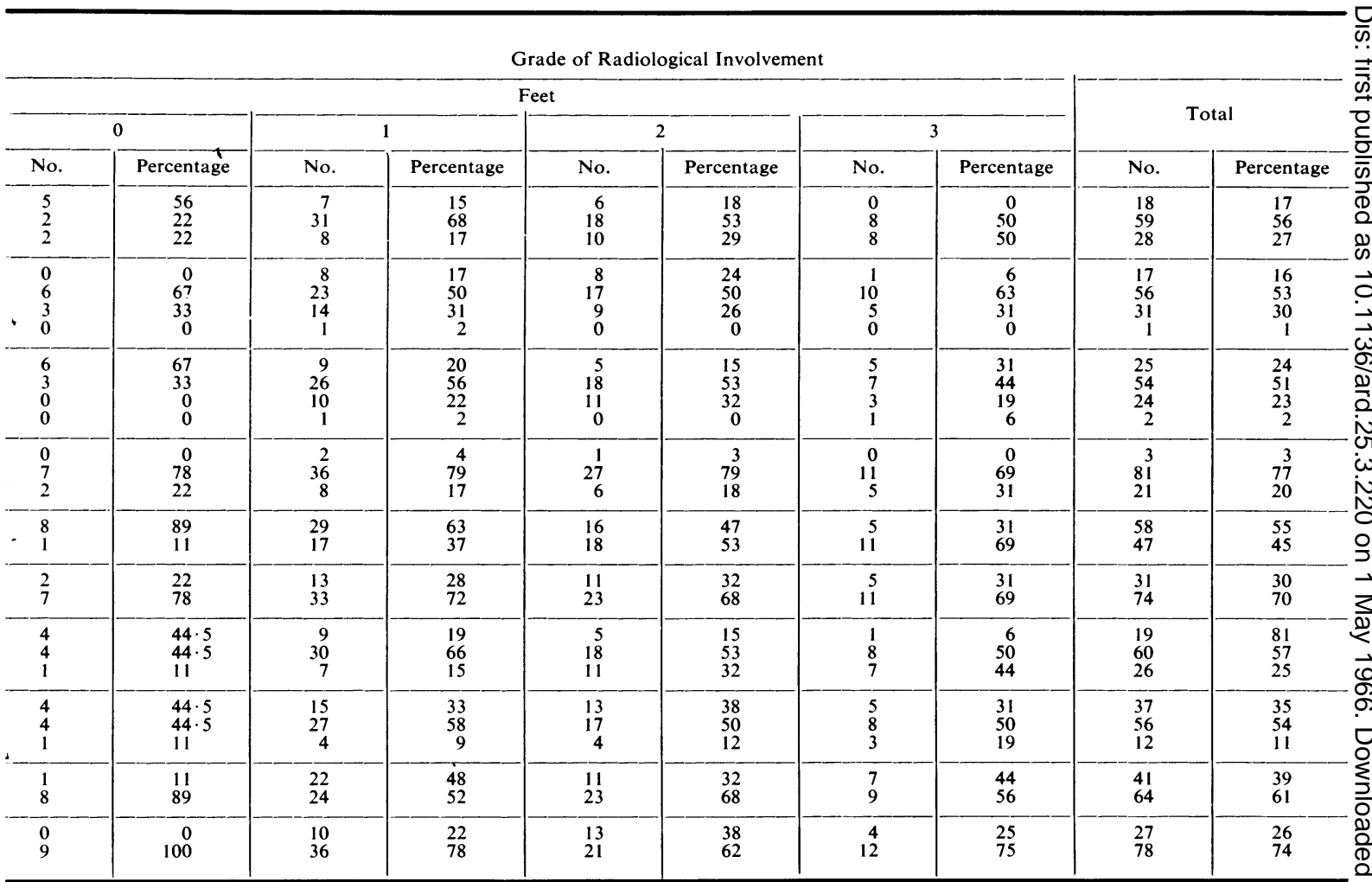

appearances have nodules, as against only one-fifth of those with Grade 0 . This relationship is much less obvious where the foot films are concerned.
There is a good correlation between the severity of hand and foot changes and duration of disease (Fig. 5). Very few of those with Grade 3 changes have
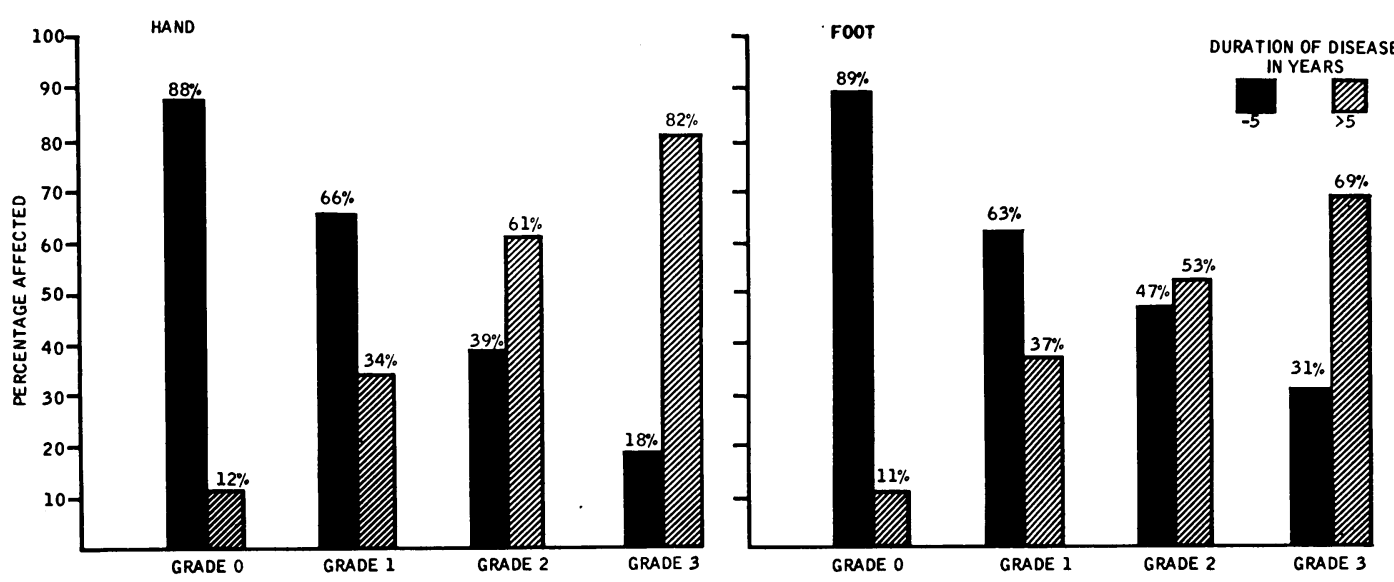

으

Fig. 5.-Degree of radiological involvement in hand and foot correlated with duration of disease. 
had the disease for less than 5 years. A similar though less marked relationship exists between the latex-fixation test and the severity of radiological changes. The correlation is better with the foot films than with those of the hand (Fig. 6). There is a slight but definite tendency for the E.S.R. to be highest in those with Grade 2 or 3 changes. There is no correlation between extent of disease as judged by numbers of groups of joints involved and severity of radiological changes. A relationship also appears to exist between the haemoglobin levels and the severity of radiological involvement. None of those with foot films of Grade 0 have a haemoglobin less than 65 per cent. Haldane, whilst 17 per cent. of those in Grade 1, 24 per cent. of those in Grade 2, and 6 per cent. in Grade 3 have values in that range. This relationship is more pronounced if the hand films are considered. Table IV shows that those with the more severe grades of radiological appearances are more likely to have had gold or corticosteroid treatment, as might be expected.

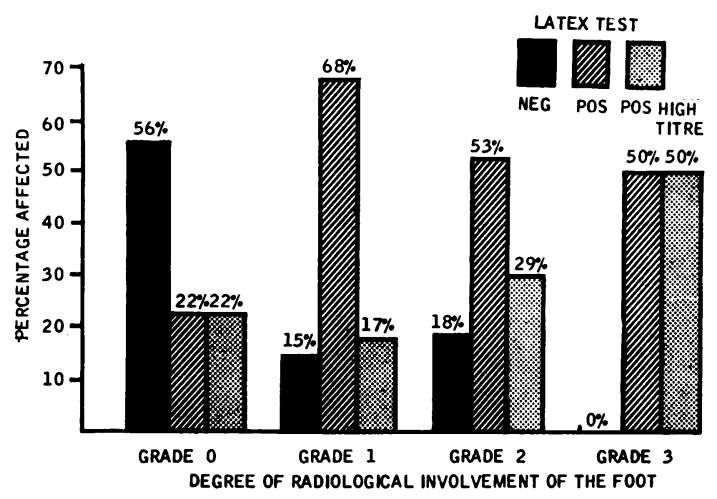

Fig. 6.-Correlation between latex-fixation test and degree of radiological involvement of the foot.

Radiological Evidence of Deterioration in the Feet. -In 37 patients serial films were available over periods up to 4 years. Table $\mathrm{V}$ shows that twelve deteriorated, as judged by increase in the number of metatarsal heads involved by rheumatoid erosions. As judged by other criteria of deterioration (subluxation, osteoporosis, cartilage loss, etc.), ten worsened by at least one grade: five deteriorated from Grade 0 to 1, two from Grade 0 to 2, three from Grade 1 to 2, and none from Grade 2 to 3 . Twelve showed no worsening, and three showed some slight improvement.
TABLE $\mathrm{V}$

DETERIORATION AND IMPROVEMENT IN RADIOLOGICAL INVOLVEMENT

\begin{tabular}{|c|c|c|c|c|c|c|c|}
\hline \multicolumn{6}{|c|}{ Deterioration } & \multirow{2}{*}{$\begin{array}{c}\text { No. } \\
5 \\
2 \\
3 \\
0\end{array}$} & \multirow{2}{*}{ 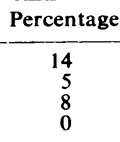 } \\
\hline \multicolumn{3}{|c|}{$\begin{array}{c}\text { Change } \\
\text { in } \\
\text { Radiological } \\
\text { Grade }\end{array}$} & \multicolumn{3}{|c|}{$\begin{array}{l}0 \text { to } 1 \\
0 \text { to } 2 \\
1 \text { to } 2 \\
2 \text { to } 3\end{array}$} & & \\
\hline $\begin{array}{c}\text { Increase in } \\
\text { Involved }\end{array}$ & $\begin{array}{l}\text { No. } \\
\text {. }\end{array}$ & $\begin{array}{l}\text { of } \\
\cdots\end{array}$ & $\begin{array}{c}\text { Metat } \\
\ldots\end{array}$ & sal & $\begin{array}{r}\text { Heads } \\
.\end{array}$ & 12 & $32 \cdot 5$ \\
\hline None .. & $\cdots$ & . & $\cdots$ & $\cdots$ & $\cdots$ & 12 & $32 \cdot 5$ \\
\hline Improvement & & . & $\ldots$ & $\cdots$ & $\cdots$ & 3 & 8 \\
\hline Total ... & $\ldots$ & $\ldots$ & $\ldots$ & $\ldots$ & $\cdots$ & 37 & $100 \cdot 0$ \\
\hline
\end{tabular}

We found positive radiological changes of rheuma- in toid arthritis in both the hands and feet in 79 (75 $\omega$ per cent.) of our patients. This is in good agree- $N$ ment with the findings in other surveys (Miall, 1955); Mason, Murray, Oates, and Young, 1959; Fletcher 은 and Rowley, 1952). A further seventeen (16 per cent.) had positive changes in the feet with normal hand radiographs, making 91 per cent. with definite radiological abnormalities in all appearing within the $\overrightarrow{\mathscr{O}}$ first few months of the disease. Of the nine ( 9 per $\%$ cent.) with negative hand and foot films, later films were available in four, and three of these developed positive changes within one year. Where only the hands are $x$-rayed, therefore, diagnostic radiological appearances of rheumatoid arthritis will be missed in $\frac{\circ}{\varnothing}$ as many as 16 per cent. of patients with the disease. $\stackrel{2}{\vec{P}}$ In consequence, it is most important in our view to $\frac{0}{3}$ take radiographs of the hands and feet simultane- $\frac{3}{5}$ ously as a routine procedure. It seems clear also that the persistent absence of radiological features of rheumatoid arthritis in both hands and feet after $\frac{0}{2}$ observing the patient for one year should raise some $\dot{\sigma}$ doubts of the diagnosis.

It would seem from our observations that the older the patient, the more likely it is that the radiological $₹$ changes in the hands and feet will be severe. No음 obvious relationship with age at onset was apparent, but there was a correlation with duration of disease for longer than 5 years. Those with severe radiological changes are more likely to have nodules S present. The presence of nodules is known to be N associated with a poor prognosis (Duthie, Broun, $\underset{\omega}{N}$ Truelove, Baragar, and Lawrie, 1964). We alsoo found a correlation between a positive latex-fixation test and severity of radiological changes. Again, $a \underset{\Phi}{\leftarrow}$ positive latex-fixation test is associated with a poor $\stackrel{\oplus}{+}$ outlook, particularly if present to a high titre (Duthie 0 and others, 1964). We observed similar relation- 0 ships between the E.S.R., haemoglobin values, and $\stackrel{\mathbb{\Omega}}{\Omega}$ 
severity of radiological changes. Both a raised E.S.R. (Duthie and others, 1964) and a lowered haemoglobin value (Gibberd, 1963; Duthie, Broun, Knox, and Thompson, 1957) are known to be associated with a poor outlook. The degree of severity of radiological changes in the hands and feet bears, therefore, a close relationship with the other known parameters of prognosis. Rheumatoid arthritis is a common disease, affecting up to 2 or 3 per cent. of the population in some areas (Kellgren, Lawrence, and Aitken-Swan, 1953). Any feature which will help to give a better understanding of the prognosis is therefore of importance. The absence of positive findings in the hand films seems to be associated with less serious disease, and disease of shorter duration. Fletcher and Rowley (1952) and Robinson, Bunim, Clark, Crain, Engleman, Graham, Montgomery, Norcross, Ragan, Ropes, Rosenberg, and Smyth (1956) also found that radiographs of the feet were more informative than those of the hands, though Mason and others (1959) found the reverse to be true.

Rheumatoid erosions in the feet involved the head of the 5th metatarsal most commonly, and the 1st metatarsal least often; this agrees with the findings of Robinson and others (1956) and Calabro (1962). The more severe the disease, the greater the number of metatarsal heads involved. The distal interphalangeal joints of the hands were affected in only four (4 per cent.), and this is in good agreement with the report of Fletcher and Rowley (1952). We found that obvious periostitis of the long bones of the fingers was not often seen, affecting only three (3 per cent.), though Mason and others (1959) observed it more frequently. Whole-hand decalcification was seen in only five ( 5 per cent.) and this is probably an uncommon feature in rheumatoid arthritis as compared with juxta-articular decalcifcation (Fletcher and Rowley, 1952). We were interested to observe that in sixteen patients ( 15 per cent.) the feet had never been painful nor the metatarsal heads tender, though all of them had definite radiological changes of rheumatoid arthritis. This small group seemed to have had their disease for only a relatively short time in the main, and the absence of symptoms in the feet was not associated with any particular age group. They appeared to have had less severe disease, too, judged by the small number of metatarsal heads involved in the group.

In 37 of our patients ( 35 per cent.) later films were available. A steady progress of deterioration seemed to be the rule, though a very small number showed some slight improvement. It has been frequently observed that though it is usual to find both the right and left sides of the body involved simultaneously in rheumatoid arthritis, the right side tends to show more severe radiological involvement than the left (Soila, 1963; Lewis-Faning, 1950), and our observations confirm this.

In conclusion, therefore, we found that radiographs of both the hands and feet should be taken routinely in the diagnosis of rheumatoid arthritis, and that the films are useful in assessing the prognosis. There is good correlation between the severity of the radiological changes and the clinical severity of the disease. Radiological examination of the feet is more useful than that of the hands.

\section{Summary}

A critical review of 105 patients with definite or classical rheumatoid arthritis was carried out with respect to their clinical state and the degree of radiological involvement of the hands and feet. In 96 (91 per cent.) there were definite radiological changes of the disease, and in seventeen (16 per cent.) the hand radiographs were normal although the foot radiographs showed the typical changes of the disease. A small group had symptomless feet although their foot films showed definite rheumatoid erosions. There was good correlation between severity of radiological changes in the hands and feet and other parameters of disease activity, notably a positive latex-fixation test, the presence of nodules, a raised E.S.R., and a lowered haemoglobin level. Most patients showed steady deterioration of the radiological changes with the passage of time.

We should like to express our great appreciation to Dr. $\mathrm{H}$. Wykeham Balme for permission to publish details of his patients, and to Mr. M. P. Curwen for his advice with the statistical treatment of our results.

\section{REFERENCES}

Calabro, J. J. (1962). Arthr. and Rheum., 5, 19.

Cecil, R. L., and Kammerer, W. H. (1951). Amer. J. Med., 10, 439.

Copeman, W. S. C. (ed.) (1955). "Textbook of the Rheumatic Diseases". Livingstone, Edinburgh.

C.I.O.M.S. (1963). "Epidemiology of Chronic Rheumatism", vol. 2, "Atlas of Standard Radiographs of Arthritis". Blackwell, Oxford.

Duthie, J. J. R., Brown, P. E., Knox, J. D. E., and Thompson, M. (1957). Ann. rheum. Dis., 16, 411.

, - , Truelove, L. H., Baragar, F. D., and Lawrie, A. J. (1964). Ibid., 23, 193.

Fletcher, D. E., and Rowley, K. A. (1952). Brit. J. Radiol., 25, 282.

General Register Office (1964). “Census, 1961. England and Wales: Age, Marital Condition, and General Tables". H.M.S.O., London. 
Gibberd, F. B. (1963). Ann. rheum. Dis., 22, 279.

Kellgren, J. H., and Lawrence, J. S. (1957). Ibid., 16, 485.

- - -

Lewis-Faning, E. (ed.) (1950). "Empire Rheumatism Council Report". Ibid., Suppl. to vol. 9.

Mason, R. M., Murray, R. S., Oates, J. K., and Young, A. C. (1959). J. Bone Jt Surg., 41B, 137.

Miall, W. E. (1955). Ann. rheum. Dis., 14, 150.

Robinson, W. D., Bunim, J. J., Clark, W. S., Crain, D. C., Engleman, E. P., Graham, D. C., Montgomery, M. M., Norcross, B. M., Ragan, C., Ropes, M.W., Rosenberg, E. F., and Smyth, C. J. (1956). Ann. intern. Med., 45, 831.

Ropes, M. W., Bennett, G. A., Cobb, S., Jacox, R., and Jessar, R. A. (1959). Ann. rheum. Dis., 18, 49.

Soila, P. (1963). Acta rheum. scand., 9, 264.

Evaluation des altérations radiologiques des mains et des pieds dans l'arthrite rhumatismale et leur corrélation avec le pronostic

\section{RÉSUMÉ}

On passa en revue 105 malades atteints d'arthrite rhumatismale "définie" et "classique" pour considérer leur état clinique et le degré d'implication radiologique de leur mains et pieds. Chez 96 d'entre eux ( 91 pour cent) on trouva des signes radiologiques définis de la maladie et chez 17 d'entre eux (16 pour cent) les radiographies des mains furent normales tandis que celles des pieds montrèrent des altérations typiques. Un petit groupe de malades n'accusa pas de symptômes, mais les radio- $-\frac{\mathbb{D}}{3}$ graphies de leurs pieds montrèrent des érosions rhumatismales évidentes. On observa une bonne corrélation $\square$. entre la sévérité des altérations radiologiques aux mains, et aux pieds et les autres paramètres de l'activité morbide, $\overrightarrow{\vec{A}}$ tels que la réaction de fixation au latex, la présence des $\stackrel{\rightarrow}{\rightarrow}$ nodules, la V.S.G. élevée et un taux bas de l'hémoglobine:o La plupart des malades accusèrent, avec le passage de temps, une détérioration radiologique progressive.

La valoración de las alteraciones radiológicas en las manos y en los pies en la artritis reumatoide y su correlación con $\vec{\circ}$ el pronóstico

\section{SUMARIO}

Se pasa revista a 105 casos de artritis reumatoide "definida" y "clásica" respecto a su estado clínico y la intensidad de la implicación radiológica de sus manos y pies. En 96 casos (91 por ciento) se encontraron signos $\omega$ radiológicos definidos de la enfermedad y en 17 casos (16î por ciento) las radiografías de las manos fueron normales aunque las de los pies revelaron alteraciones típicas. $\mathrm{Un}_{\mathrm{O}}$ pequeño grupo de enfermos fué asintomático, aunque las radiografías de los pies revelasen erosiones reumatoides claras. Se notó una buena correlación entre la severidadక de las alteraciones radiológicas en las manos y en los pies y los demás parametros de la actividad morbosa, talescomo la reacción de fijación de latex, la presencia de nódulos, la velocidad de sedimentación eritrocitariặ elevada y cifras bajas de hemoglobina. La mayoría de los enfermos acusaron, al pasar el tiempo, una deteracióno radiológica progresiva. 